\title{
BIRCH (Betula L.) POLLEN SEASONS IN CRACOW IN 1991-2008 IN RELATION TO METEOROLOGICAL CONDITIONS
}

\author{
${ }^{1}$ Dorota Myszkowska, ${ }^{2}$ Katarzyna Piotrowicz \\ ${ }^{1}$ Department of Clinical and Environmental Allergology, Jagiellonian University Medical College, \\ Śniadeckich 10, 31-531 Cracow, Poland \\ e-mail: dmyszkow@cm-uj.krakow.pl \\ ${ }^{2}$ Department of Climatology, Jagiellonian University, Gronostajowa 7, 30-387 Cracow, Poland
}

Received: 2.08.2009

\section{Abstract}

The parameters of the birch pollen seasons in Cracow in 1991-2008 were analysed in relation to some meteorological elements and synoptic situations (circulation types, air masses and atmospheric fronts). Two types of the pollen seasons were distinguished - highly dense and less dense. The first type of the season started on the $15^{\text {th }}$ of April (on average), lasted 11-20 days and the maximum daily concentration exceeded $500 \mathrm{pgm}^{-3}$. The less dense type started generally earlier (the first decade of April), lasted more than 20 days and the peak days were unstable. In this type of the pollen season, two peak days were often observed. The relationship between the type of the season and the meteorological conditions before the season was pointed out. Additionally, the influence of circulation types, types of air masses and atmospheric fronts over south-eastern Poland on a given day on the number of days with a daily concentration $>$ $80 \mathrm{pgm}^{-3}$ was analysed. The relationship between the pollen season type and meteorological conditions before the season was found, among others, the influence of types of synoptic situations and air masses on the number of days with a concentration of over $80 \mathrm{pgm}^{-3}$ was established.

Key words: aerobiology, Betula, pollen season types, meteorological conditions, Cracow

\section{INTRODUCTION}

Blooming, pollen release and development of birch leaves occur almost simultaneously, usually in April. In Poland two of the most common species of birch are found (Betula pendula Roth and Betula pubescens Ehrh.) (S eneta and Dolatowski, 2007).

Birch pollen allergens cause inhalant allergy in the North and Central Europe, including Poland (D'A mato et al. 2007). S piek s ma (1991) and Mattiesen et al. (1991) consider birch pollen as highly allergenic. In Poland about $50 \%$ of patients with pollen allergy is sensitive to birch pollen, but about 10$15 \%$ of this group is monosensitive to these allergens (Małolepszy et al. 2000).

For medical and scientific purposes, pollen monitoring has been performed in Cracow since 1982 (S z c ze p a n e k, 1994). In the years 1982-1997 the gravimetric method was used, whereas in 1991 the volumetric method was introduced (Myszkowska, 2006). The results of pollen monitoring in Cracow showed that the birch pollen had the highest percentage among tree pollen (M y s z k o w s k a et al. 2007). There is a significant relationship between Betula pollen season severity and weather conditions (daily average temperature and rainfall), both in the year before pollination and in the same year that pollen is released from the plant. In addition, the Betula pollen seasons in Cracow do not appear to be influenced by the NAO (North Atlantic Oscillation), which is probably the result of Cracow having a more continental climate (S tach et al. 2008).

The aim of this study was to define some regularity of the long series of pollen data in Cracow and to find the relationship between some parameters and meteorological elements and synoptic situations.

\section{MATERIALS AND METHODS}

The daily pollen concentration was obtained by the volumetric method in 1991-2008. The Hirsttype sampler was located in the centre of Cracow on the roof of the Collegium Śniadecki building, near the Botanical Garden $\left(50^{\circ} 04^{\prime} \mathrm{N}, 19^{\circ} 58^{\prime} \mathrm{N}, 25 \mathrm{~m}\right.$ above ground level (AGL). The pollen seasons were calculated using the $95 \%$ method. The start of the season was defined as the date when $2.5 \%$ of the seasonal cumulative pollen count was trapped and the end of the season as the date when $97.5 \%$ of the seasonal cumulative pollen count 
was reached ( $\mathrm{Ni} 1 \mathrm{~s} \mathrm{~s}$ on and Pers s o $\mathrm{n}, 1981)$. The following seasonal parameters were used to characterize the pollen season dynamics and the variability of the seasons: season start and end dates, season duration, annual pollen total and peak concentrations, as well as meteorological elements such as: air temperature, relative humidity, relative sunshine duration, wind. They were described using classical statistical parameters, like: minimum and maximum values (min, max), arithmetic mean $(\bar{x})$, standard deviation $(s)$, coefficient of variation $(V \%)$. The Department of Climatology at the Jagiellonian University provided us with meteorological data recorded at the weather station located in the immediate vicinity of the monitoring site. Additionally, the catalogue of synoptic situations for each day, where synoptic situation type, kind of air masses and atmospheric fronts were defined in the upper Vistula river basin in Southern Poland ( $\mathrm{N}$ i e d ź w i e d ź, 2009), was used in the analysis.

\section{RESULTS}

In Cracow, in 1991-2008 the birch pollen seasons started most often in the first half of April (approx. on the $13^{\text {th }}$ of April) (Tab. 1). The earliest start was in 2002 (29 th $^{\text {th }}$ March), the latest in 1996 (24 $4^{\text {th }}$ of April) (Tab. 1, Fig. 1). The pollen season end dates were more variable comparing to the start dates. The season end date was observed between the $20^{\text {th }}$ of April (1999) and $5^{\text {th }}$ of July (1996). Most often the season was over in the first half of May (approx. on the $7^{\text {th }}$ of May) (Tab. 1). On average, the season lasted 24 days (Tab. 1). The shortest seasons were noted in 1993 and 1995 (11 days), the longest one in 1996 (72 days) (Tab. 1, Fig. 1).

With regard to the start and end pollen season dates, as well as duration of the season, two types of birch pollen seasons were recognized (Tab. 1). The first type of highly dense occurrence started in the second

Table 1

The descriptive statistics of the birch pollen season parameters in Cracow in the period 1991-2008.

\begin{tabular}{|c|c|c|c|c|c|c|c|c|c|}
\hline \multirow{2}{*}{$\begin{array}{l}\text { Parameter } \\
\text { value }\end{array}$} & \multirow{2}{*}{$\begin{array}{c}\text { Annual } \\
\text { pollen sum }\end{array}$} & \multicolumn{3}{|c|}{ Maximum daily concentration } & \multicolumn{2}{|c|}{ Season start* } & \multicolumn{2}{|c|}{ Season end* } & \multirow{2}{*}{$\begin{array}{l}\text { Season duration } \\
\text { (number of days) }\end{array}$} \\
\hline & & $\begin{array}{c}\text { Pollen } \\
\text { concentration }\end{array}$ & $\begin{array}{l}\text { Day of } \\
\text { the year }\end{array}$ & Date & $\begin{array}{l}\text { Day of } \\
\text { the year }\end{array}$ & Date & $\begin{array}{l}\text { Day of } \\
\text { the year }\end{array}$ & Date & \\
\hline \multicolumn{10}{|c|}{ All analysed pollen season in 1991-2008 } \\
\hline $\min$ & 803 & 119 & 108 & 18.04 & 88 & 29.03 & 110 & 20.04 & 11 \\
\hline $\max$ & 8649 & 2009 & 103 & 12.04 & 114 & 24.04 & 186 & 5.07 & 72 \\
\hline $\bar{x}$ & 3078.6 & 691.1 & - & - & 103 & 13.04 & 127 & 7.05 & 24 \\
\hline$s$ & 2279.6 & 521.9 & - & - & 7.0 & - & 15.5 & - & 14.5 \\
\hline$V \%$ & 74.0 & 75.5 & - & - & 6.8 & - & 12.2 & - & 59.5 \\
\hline \multicolumn{10}{|c|}{ More dense pollen seasons (1992-1995, 1999-2001, 2003 i 2005) } \\
\hline $\min$ & 959 & 210 & 106 & 15.04 & 94 & 4.04 & 110 & 20.04 & 11 \\
\hline $\max$ & 8649 & 1729 & 114 & 24.04 & 112 & 22.04 & 123 & 3.04 & 19 \\
\hline $\bar{x}$ & 3176.4 & 754.2 & - & - & 105 & 15.04 & 120 & 30.04 & 14.6 \\
\hline$s$ & 2408.7 & 501.1 & - & - & 5.2 & - & 4.0 & - & 2.7 \\
\hline$V \%$ & 75.8 & 66.4 & - & - & 5.0 & - & 3.3 & - & 18.6 \\
\hline \multicolumn{10}{|c|}{ Less dense pollen seasons $(1991,1996-1998,2002,2004,2006-2008)$} \\
\hline $\min$ & 803 & 119 & 108 & 18.04 & 88 & 29.03 & 118 & 28.04 & 21 \\
\hline $\max$ & 7468 & 2009 & 103 & 12.04 & 114 & 24.04 & 186 & 5.07 & 72 \\
\hline $\bar{x}$ & 2980.7 & 628.0 & - & - & 100 & 10.04 & 134 & 14.05 & 34.3 \\
\hline$s$ & 2138.2 & 534.5 & - & - & 7.3 & - & 19.1 & - & 14.8 \\
\hline V\% & 71.7 & 85.1 & - & - & 7.3 & - & 14.2 & - & 43.2 \\
\hline
\end{tabular}

*start and end of the season calculated on the basis of $95 \%$ method 
Table 2

The frequency of the days with the birch pollen concentration over $80 \mathrm{pgm}^{-3}$ in Cracow in the period 1991-2008 in the defined types of synoptic situations, air masses and atmospheric fronts (acc. to Niedźwiedź's catalogue).

\begin{tabular}{|c|c|c|}
\hline Symbol & Name & Frequency $(\%)$ \\
\hline \multicolumn{3}{|c|}{ Circulation types } \\
\hline $\mathrm{E}+\mathrm{SEa}$ & Anticyclonic situations with advection of air masses from east and south-east & 18.0 \\
\hline $\mathrm{Ca}+\mathrm{Ka}$ & Central anticyclonic situation, anticyclonic wedge & 16.1 \\
\hline $\mathrm{Cc}+\mathrm{Bc}$ & Central cyclonic situation, trough of low pressure & 16.1 \\
\hline $\mathrm{S}+\mathrm{SWc}$ & Cyclonic situations with advection of air masses from south and south-west & 10.6 \\
\hline $\mathrm{S}+\mathrm{SWa}$ & Anticyclonic situations with advection of air masses from south and south-west & 9.3 \\
\hline $\mathrm{E}+\mathrm{SEc}$ & Cyclonic situations with advection of air masses from east and south-east & 8.1 \\
\hline $\mathrm{W}+\mathrm{NWc}$ & Cyclonic situations with advection of air masses from west and north-west & 8.1 \\
\hline $\mathrm{W}+\mathrm{NWa}$ & Anticyclonic situations with advection of air masses from west and north-west & 6.2 \\
\hline $\mathrm{N}+\mathrm{NEa}$ & Anticyclonic situations with advection of air masses from north and north-east & 3.1 \\
\hline $\mathrm{N}+\mathrm{NEc}$ & Cyclonic situations with advection of air masses from north and north-east & 1.2 \\
\hline $\mathrm{x}$ & Unclassified situation & 3.1 \\
\hline \multicolumn{3}{|c|}{ Air masses } \\
\hline $\mathrm{PPk}$ & Polar continental & 32.3 \\
\hline PPms & Polar maritime old (transformed) & 29.8 \\
\hline PPmc & Polar maritime warm & 11.2 \\
\hline PPm & Polar maritime (fresh) & 9.9 \\
\hline $\mathrm{rmp}$ & Various air masses in day & 8.7 \\
\hline $\mathrm{PZ}$ & Tropical air masses & 6.2 \\
\hline $\mathrm{PA}$ & Arctic air masses & 1.9 \\
\hline \multicolumn{3}{|c|}{ Atmospheric fronts } \\
\hline- & Day without front & 65.3 \\
\hline $\mathrm{z}$ & Cold front & 11.8 \\
\hline $\mathrm{c}$ & Warm front & 9.9 \\
\hline st & Stationary front & 6.2 \\
\hline $\mathrm{r}$ & Several various fronts in a day & 4.3 \\
\hline o & Occluded front (occlusion) & 2.5 \\
\hline
\end{tabular}




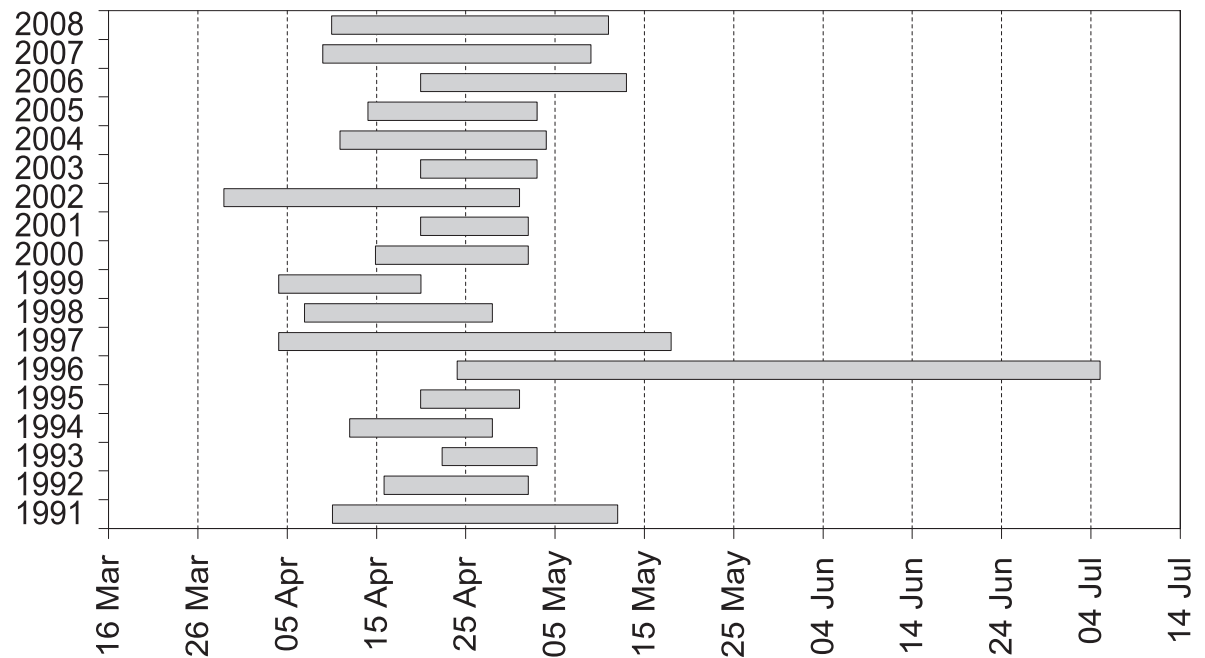

Fig. 1. Birch pollen seasons in Cracow in the period 1991-2008 (calculated using the 95\% method).

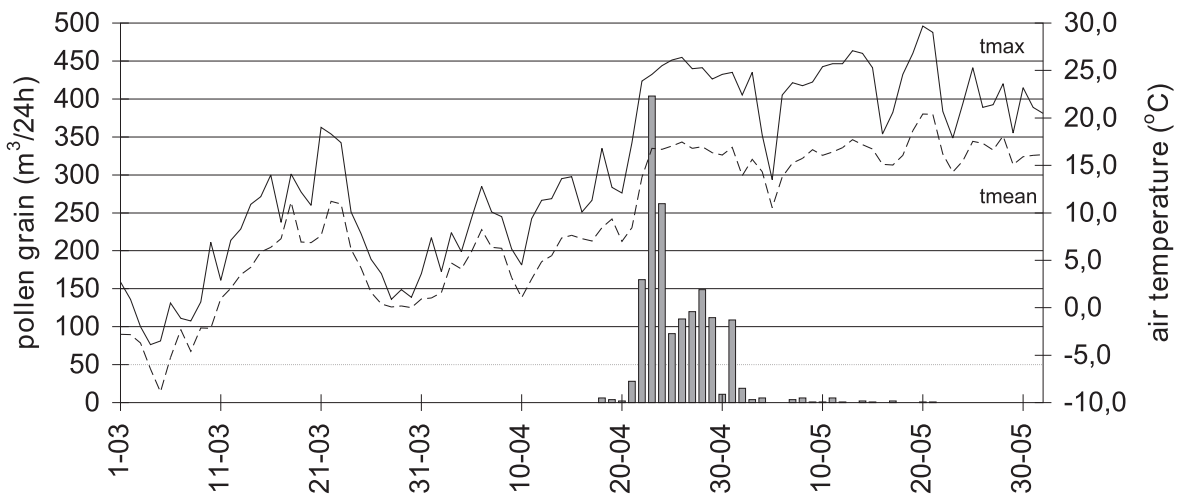

Fig. 2. Daily birch pollen concentrations and maximum (tmax) and mean air temperature (tmean) in Cracow in 1993 - an example of highly dense pollen type.

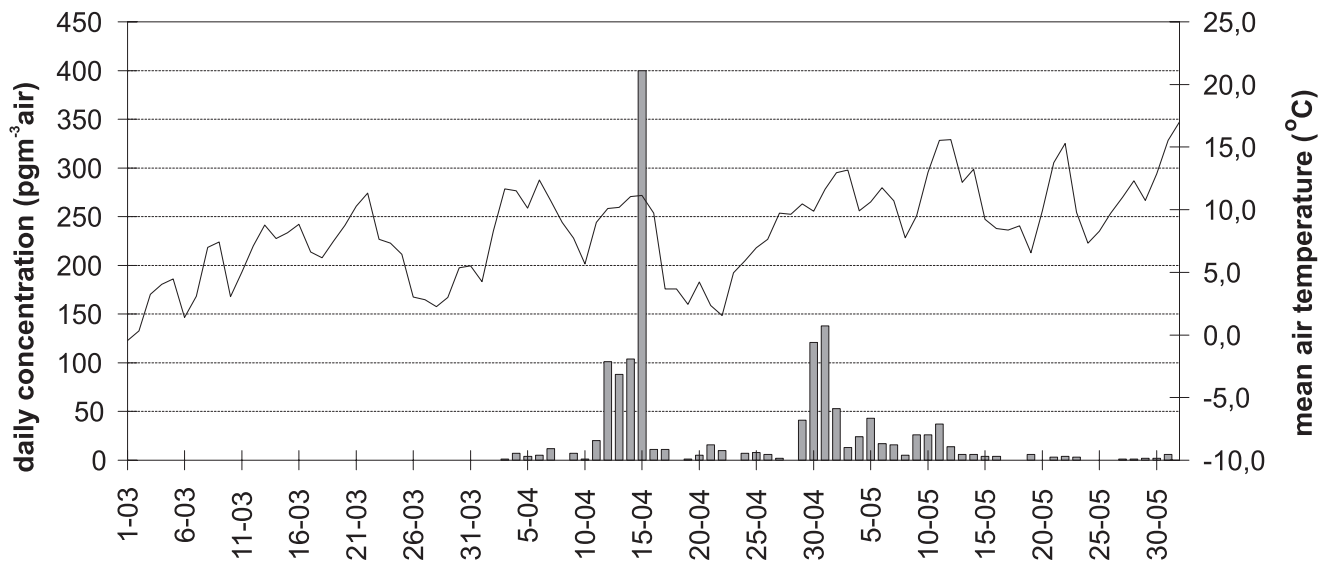

Fig. 3. Daily birch pollen concentrations and maximum (tmax) and mean air temperature (tmean) in Cracow in 1991 - an example of less dense pollen type. 


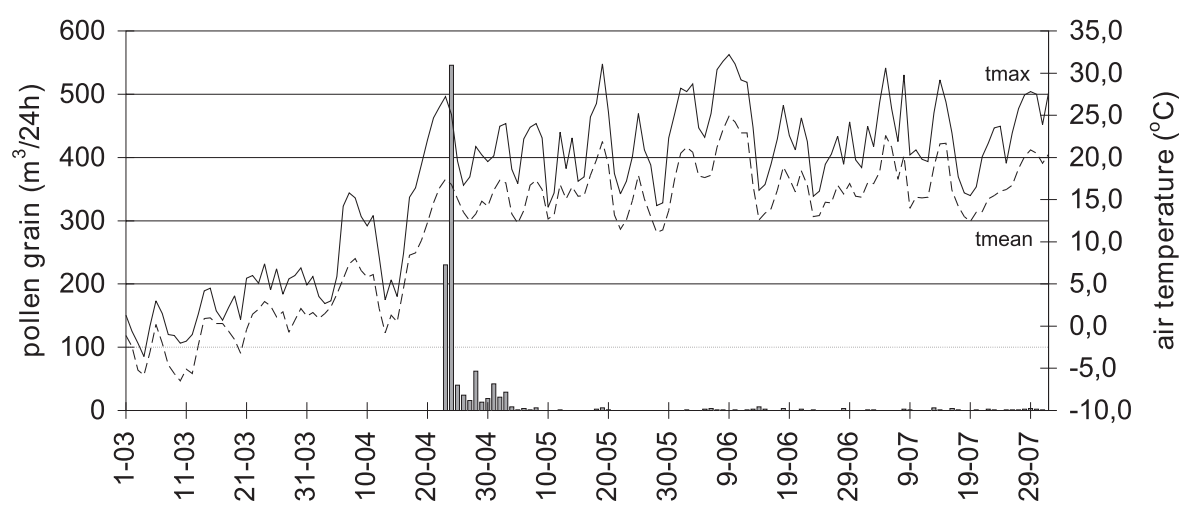

Fig. 4. Daily birch pollen concentrations and maximum (tmax) and mean air temperature (tmean) in Cracow in 1996.

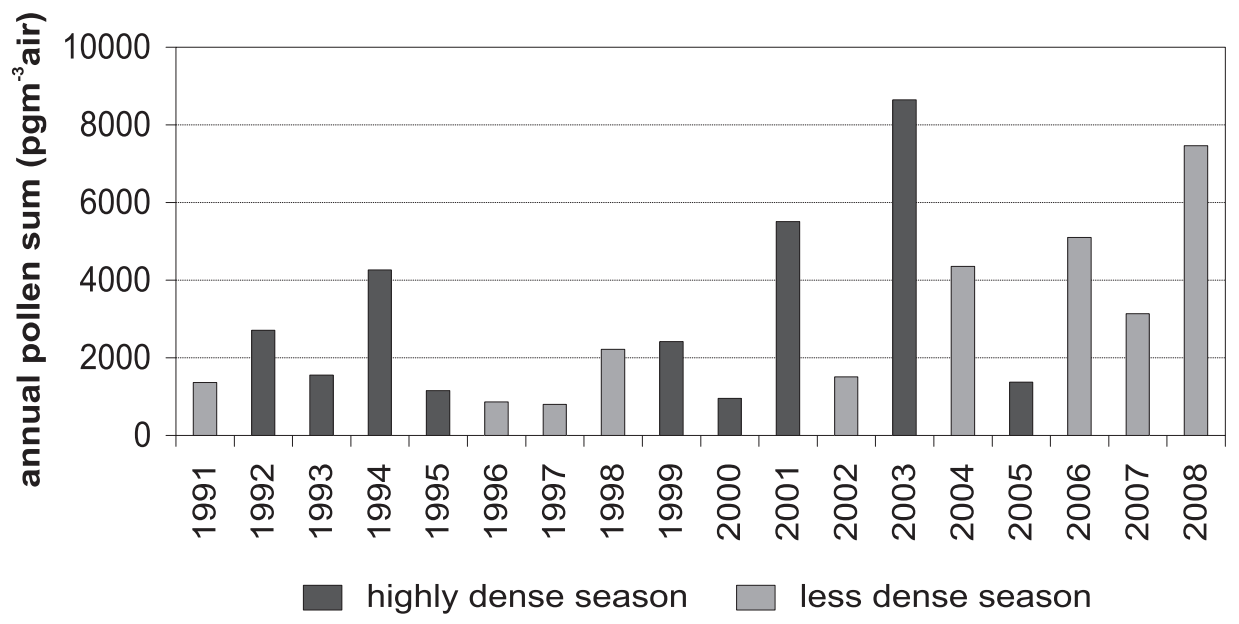

Fig. 5. Annual birch pollen sums in Cracow in the period 1991-2008.

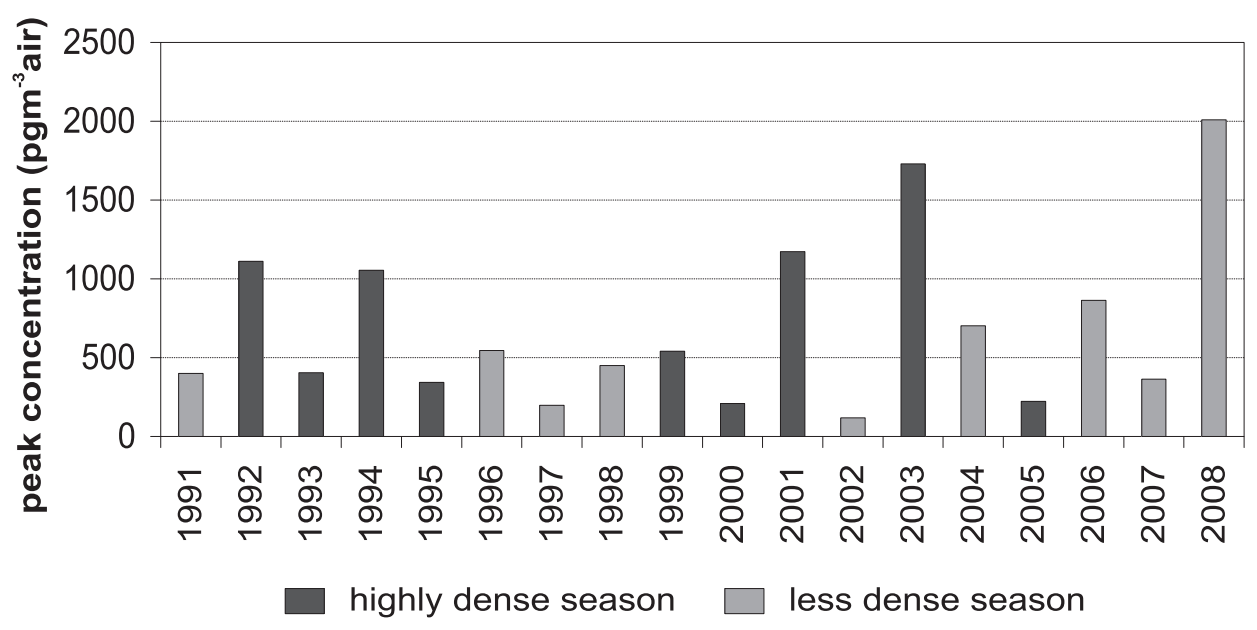

Fig. 6. Values of birch peak concentrations in Cracow in the period 1991-2008. 


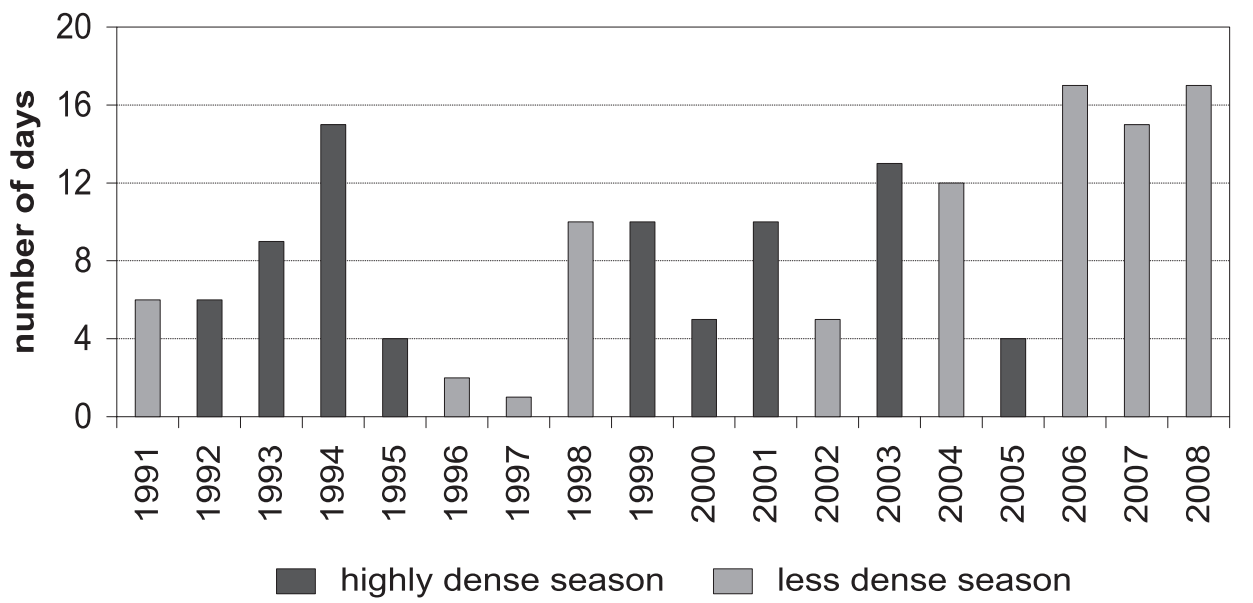

Fig. 7. The number of days with daily birch pollen concentration over $80 \mathrm{pgm}^{-3}$ in Cracow in the period 1991-2008.

half of April (approx. on the 15 ${ }^{\text {th }}$ of April), lasted 11-20 days and the maximum concentration was higher than $500 \mathrm{pgm}^{-3}$ (it was less variable than in the second type, V\%=66.4) (Tab. 1). This type occurred in Cracow in the following years: 1992-1995, 1999-2001, 2003 and 2005 (Fig. 2). The second pollen season type (less dense) started earlier in the first decade of April (approx. on the $10^{\text {th }}$ of April) and lasted more than 20 days (approx. 34 days) (Tab. 1). The seasons of the second type were characterized by high variability of the peak day dates $(\mathrm{V} \%=85.1)$, although there was a low variability of the annual total (V\%=71.7) (Tab. 1). These seasons occurred in the following years: 1991, 1996$1998,2002,2004,2006-2008$. In this type of the season, a second peak day was often found (Fig. 3).

The pollen season in 1996 was not typical. It started very late and rapidly (230 $\mathrm{pgm}^{-3}$ in the first day) and lasted very long (72 days) (Fig. 4). The most pollen grains were observed in the first 11 days of the season, so it was the first type of the season.

The highest annual pollen sum was achieved in 2003 (more than $8000 \mathrm{pgm}^{-3}$ ), the lowest in 1997 (803 $\mathrm{pgm}^{-3}$ ) (Fig. 5). The annual sums were slightly higher in the first season type (mean annual total for the first type $=2408.7$; for the second type $=2138.2)($ Tab. 1$)$.

No evident relationship between the peak value and season type was found. The highest peak value was noted in $2008\left(2009 \mathrm{pgm}^{-3}\right)$, while the lowest in 2002 $\left(199 \mathrm{pgm}^{-3}\right)$. Both these seasons were classified as less dense. Also, a higher variability of the peak value was estimated in the fist type of season $(\mathrm{V} \%=66.4)$, in comparison with the second type of season $(\mathrm{V} \%=85.1)$ (Tab. 1).
In the analysed seasons in Cracow, a different number of days with a daily concentration $>80 \mathrm{pgm}^{-3}$ was noted, from 1 (in 1997) to 17 (in 2006 and 2008) (Fig. 7). The days with $\mathrm{pgm}^{-3}>80$ were noted when there occurred anticyclonic situations with the advection of air masses from east or southeast $(\mathrm{E}+\mathrm{SEa})$, central anticyclonic situation or anticyclonic wedge $(\mathrm{Ca}+\mathrm{Ka})$ and central cyclonic situation or cyclonic trough ( $\mathrm{Cc}+\mathrm{Bc})$ (Tab. 2). These synoptic situations as well as fresh and transformed air masses are precisely predicted by meteorologists. The days with a concentration of over $80 \mathrm{pgm}^{-3}$ occurred when polar continental (PPk) or polar maritime transformed air masses (PPms) were coming to the south-eastern part of Poland. In $65.3 \%$ of the days in question, atmospheric fronts did not occur (Tab. 2).

\section{DISCUSSION}

During aerobiological monitoring, pollen grains of few different birch species were identified. In Cracow and its close vicinity $B$. pendula dominates. B. pubescens grows only on single sites in the Niepołomice forest and in the north-western part of Cracow. B. pendula starts to bloom in the second part of April to the end of May, while B. pubescens about two weeks later than B. pendula (S e neta and Dolatowski, 2007).

In spite of the difference in florescence of particular species, the birch pollen season is rather dense, with one evident peak day ( $\mathrm{S}$ z c z e p a n e k, 1994; Latałowa et al. 2002; Myszkowska et al. 2007). The pollen season pattern is asymmetric and 
skew to the right. In the opinion of $\mathrm{H} \mathrm{y} \mathrm{d} \mathrm{e} \mathrm{(1956),} \mathrm{the}$ birch pollen season is of dense occurrence type. The number of pollen grains in the air increases gradually, reaching the peak concentration, and then declines.

On the basis of the season duration and peak value, the authors divided the seasons into two groups. The more dense season started later (second part of April) in relation to the mean start date. In the days preceding the start date, maximum air temperature exceeded $17^{\circ} \mathrm{C}$ (mean air temperature about $10^{\circ} \mathrm{C}$ ), relative humidity was lower than $70 \%$ and relative sunshine duration was over $50 \%$. Simultaneously, an anticyclonic situation with the advection of polar maritime transformed (PPms), warm (PPmc) or polar continental (PPk) air masses occurred in the south-eastern part of Poland. These air masses, coming to Poland in spring, cause usually warm, sunny and a little cloudy weather. They are relatively dry, usually with no rainfall or in case of PPms with low precipitation (W o ś, 1999; T w a r d o s z, 2005). PPms, PPmc and PPk air masses occurring in the south-eastern part of Poland for several days are the reason for fast vegetation development. However, arctic (PA) and polar maritime (PPm) air masses, found in spring, cause coolness with possible ground frost which could stop vegetation development.

The second season type, less dense, occurs earlier (first decade of April) and it usually follows weather patterns in March (high temperature). However, at the end of March and at the beginning of April weather is usually variable. Then, a few-day-long coolness occurs which extends the pollen season. More than once the coolness was the reason for the increase in pollen concentration once again (the second peak).

The pollen season in 1996 was a different one. It started very late and lasted the longest due to meteorological factors prevailing at that time. In the first half of April, there was still a snow cover in Cracow, minimum temperature was below $0^{\circ} \mathrm{C}$ and maximum temperature exceeded $10^{\circ} \mathrm{C}$ during the day only sporadically. On the $17^{\text {th }}$ of April, the weather changed and then the ground frost was over and maximum temperature exceeded $20^{\circ} \mathrm{C}$.

On the $17^{\text {th }}$ of April the weather changed and then the ground frost was over and maximum air temperature increased above $15^{\circ} \mathrm{C}$ (mean air temperature exceeded $10^{\circ} \mathrm{C}$ ).

Such a long-lasting pollen season in Cracow and its close vicinity, when the florescence of birch was over, evidenced the long-distance transport of birch pollen grains. These pollen grains are very light and of aerodynamic shape, which favours their distribution for long distances. Meteorological factors can also influence pollen distribution patterns. An average distance of birch pollen distribution is $117.7 \mathrm{~km}$ (D y a kow ska, 1959).
When an anticyclonic situation occurs in southeastern Poland, the wind blows from southerly or easterly directions and relative humidity of the air is low, then pollen grains are transported to the Cracow area from the Bieszczady Mountains where the birch florescence occurs later. The long-lasting presence of pollen grains in the air could be also caused by redeposition.

The annual pollen totals seem to be very variable from year to year, especially in case of tree pollens. The authors did not observe the alternate cycle of high and low annual totals indicated by $\mathrm{L}$ a $\mathrm{t}$ a $\nmid$ o w a et al. (2002). It is clearly seen that the annual totals were lower in the period 1991-2000 than in 2001-2008. Rather, it is not associated with the increase in the birch population in Cracow, but with the optimal meteorological conditions. The number of pollen grains in the season is dependent on weather conditions in the preceding year when the sporogenic tissue starts to develop (S a r v a s, 1972).

On the basis of many years' aeropalinological observations at different sites in Europe, annual pollen concentration trends were defined. Weak increasing trends were observed by J ä g e r et al. (1991) in Brussels (Belgium) and Leiden (Netherlands), by R u f f a 1 dii and Greffier (1991) in France (multi-center study), by Cord e $\mathrm{n}$ et al. (2000) in London (UK) and by P u c (2006) in Szczecin (Poland). The last mentioned author explained that her results required confirmation in the coming years. No relationship between the annual pollen total and season duration was found, which was observed by L a t a 1 ow a et al. (2002) and S pieksma et al. (1995).

For patients sensitive to birch allergens, information about the peak value and the threshold value are important (T a u dorf and Mos e holm, 1988). Unfortunately, the estimation of the threshold value is difficult, because it highly depends on personal sensitivity ( $\mathrm{N}$ o r m a n, 1969). Viander and Koivikko (1978) indicated that at the beginning of the season, in $90 \%$ of patients sensitive to birch allergens the allergy symptoms started when the daily pollen concentration exceeded $80 \mathrm{pgm}^{-3}$. Later in the season, only $30 \mathrm{pgm}^{-3}$ was enough to induce the symptoms. In this paper, the number of days with pgm $>80$ was similar in both types of the season. Similar results (1-14 days) were obtained by $\mathrm{S} \mathrm{t} \mathrm{a} \mathrm{c} \mathrm{h} \mathrm{et} \mathrm{al.} \mathrm{(2008)} \mathrm{who} \mathrm{com-}$ pared the seasonal parameters in Cracow and Poznań. In Cracow the number of days with a concentration $>80$ pogm $^{-3}$ was lower than in Poznań and an increasing trend in annual pollen concentration changes in 1995-2005 was found (statistically not significant).

The analysis of daily pollen concentrations with regard to some types of synoptic situations, the influence of defined air masses and atmospheric fronts is a new approach to explain the variety of the pollen seasons. 
Precise forecasting of some synoptic situations by meteorologists may be useful for seasonal predictive model construction. In the authors' opinion, such an analysis of birch pollen seasons at other sites in Poland would be of great value. It is likely that the relationship between pollen concentrations and synoptic situations could also appear in the other regions of the country.

\section{CONCLUSIONS}

1. The analysis of the birch pollen seasons in Cracow in 1991-2008 indicated differentiation of the seasonal parameters (season start and end dates, season duration, number of days with a concentration over $80 \mathrm{pgm}^{-3}$ ).

2. Two types of the pollen season were distinguished: highly dense and less dense.

3. The relationship between the type of the pollen season and meteorological conditions before the season was found.

4. The influence of different types of synoptic situations, air masses and atmospheric fronts on a given day in south-eastern Poland on the number of days with a concentration over $80 \mathrm{pgm}^{-3}$ was established.

This study was supported by the project grants of the Ministry of Science and Higher Education No. N306 049 32/3237 (2007-2009) and No. N305 021236 (2009-2011).

\section{REFERENCES}

Corden J., Millington W., Bailey J., Brookes M., Caulton E., Emberlin J., Mullins J., Simps on C., Wood A., 2000. UK regional variations in Betula pollen (1993-1997). Aerobiologia, 16: 227 232.

D'A mato D., Cecchi L., Bonini S., Nunes C., Annesi-Maesano I., Behrendt H., Liccardi G., Popov T., van Cauwenberge P., 2007. Allergenic pollen and pollen allergy in Europe. Allergy. 62 (9): 976-990.

Dyakowska J., 1959. Podręcznik palynologii. Metody i problemy. Wyd. Geologiczne, Warszawa.

Hyde H. A., 1956. Tree pollen in Great Britain. Acta Allerg. 10: 224-245.

Jäger S., Spieksma F. T. M., Nolard N., 1991. Fluctuation and trends in airborne concentrations of some abundant pollen types, monitored at Vienna, Leiden and Brussels. Grana, 30: 309-312.

Latałowa M., Miętus M., Uruska A., 2002. Seasonal variations in the atmospheric Betula pollen count in Gdańsk (southern Baltic coast) in relation to meteorological parameters. Aerobiologia, 18: 33-43.

Małolepszy J., Liebhart J., Wojtyniak B., Pysiewicz K., Płuska T., 2000. Występowanie chorób alergicznych w Polsce. / The occurence of allergic diseases in Poland. Alergia Astma Immunologia, 5 (2): 163-169.

Mattiesen F., Ipsen H., Lřwenstein H., 1991. Pollen Allergens. [In:] Allergenic pollen and pollinosis in Europe. G. D' A m a t o., F. Th. M. Spieksma, S. Bonini (ed), Blackwell Sci. Publ., Oxford, London, Edinburgh, Boston, Melbourne, Paris, Berlin, Vienna: 36-44.

Myszkowska D., 2006. Pyłek wybranych taksonów roślin w powietrzu Krakowa, 2001-2005. [In:] E. Weryszko-Chmielewska (ed.), Pyłek roślin w aeroplanktonie różnych regionów Polski: 21-30, Wyd. Katedra i Zakład Farmakognozji AM, Lublin (in Polish).

Myszkowska D., Jenner B., Cywa K., Kuropatwa M., Stępalska D., Piotrowicz K., 2007. Sezony pyłkowe wybranych taksonów drzew i krzewów w Krakowie i okolicy. / Pollen seasons of selected tree and shrub taxa in Kraków and its neighbourhood. Acta Agrobot. 60 (2): 71-77.

Niedźwiedź T., 2009. Kalendarz sytuacji synoptycznych dla dorzecza Górnej Wisły. / Catalogue of synoptic situations in the upper Vistula river basin, Plik komputerowy dostępny w Katedrze Klimatologii, Wydz. Nauk o Ziemi UŚ, Sosnowiec / Computer file available at the Department of Climatology, University of Silesia.

Nilss on S., Pers son S., 1981. Tree pollen spectra in the Stockholm region (Sweden), 1973-1980. Grana, 20: 179-182.

N or m a n P. S., 1969. A rational approach to desensitization. J. Allergy, 44; 129-45.

P u c M., 2006, Pyłek brzozy w powietrzu Szczecina w latach 2000-2004. / Birch pollen in the air of Szczecin in the years 2000-2004. Acta Agrobot. 59: 325-333.

Ruffaldi P., Greffier F., 1991. Birch (Betula) pollen incidence in France (1987-1990). Grana, 30: 248-254.

S a rvas R., 1972. Investigation on the annual cycle of development of forest trees. Avtive Period. Comm. Inst. Fenn. 73;3.

S e n e t a W., D o l a t o w s k i J., 2007. Dendrologia. Państwowe Wydawnictwo Naukowe, Warszawa.

S pieks ma F. Th. M., 1991. Regional European pollen calendars. [In:] G. D'Amato, F. Th. M. Spieksma, S. Bonini (eds), Allergenic pollen and pollinosis in Europe: 4965, Blackwell Sci. Publ., Oxford, London, Edinburgh, Boston, Melbourne, Paris, Berlin, Vienna.

Spieksma F. Th. M., Emberlin J., Hjelmroos M., Jäger S., Leuschner R. M., 1995. Atmospheric birch (Betula) pollen in Europe: Trends and fluctuations in annual quantities and the starting dates of the seasons. Grana, 34: 51-57.

Stach A., Emberlin J., Adams-Groom B., Smith M., Myszkowska D., 2008. Factors that determine the severity of Betula spp. pollen seasons in Poland (Poznań and Krakow) and the United Kingdom (Worcester and London). J. Intern Biometeorol, 52 (4): 311321.

Szczepanek K., 1994. Pollen calender for Cracow (southern Poland), 1982-1991. Aerobiologia, 10 (1): 65-70. 
Taudorf E., Moseholm L., 1988. Pollen count, symptom and medicine score in birch pollinosis. A mathematical approach. Int. Arch. Allergy Appl. Immunol. 86: 225233.

Twardosz R., 2005. Dobowy przebieg opadów atmosferycznych w ujęciu synoptycznym i probabilistycznym na przykładzie Krakowa (1886-2002). / The synoptic and probabilistic aspects of diurnal precipitation variation in Cracow. Instytut Geografii i Gospodarki Przestrzennej Uniwersytetu Jagiellońskiego, Kraków.

Viander M., Koivik ko A., 1978. The seasonal symptoms of hyposensitized and untreated hay fever patients in relation to birch pollen counts: correlations with nasal sensitivity, prick tests and RAST. Clin. Allergy, 8: 387-96.

Woś A., 1999. Klimat Polski. Państwowe Wydawnictwo Naukowe, Warszawa.

\section{Charakterystyka sezonu pyłkowego brzozy (Betula L.) \\ w Krakowie na tle warunków meteorologicznych}

\section{Streszczenie}

W pracy dokonano analizy zróżnicowania parametrów sezonów pyłkowych brzozy w Krakowie w latach 1991-2008 w zależności od przebiegu wybranych elementów meteorologicznych i sytuacji synoptycznych (typów cyrkulacji mas powietrza i frontów atmosferycznych. Wyróżniono dwa podstawowe typy sezo- nu pyłkowego brzozy - bardzo zwarty i mniej zwarty. Pierwszy rozpoczynał się średnio 15 kwietnia, trwał przez 11-20 dni a maksymalne dobowe stężenie najczęściej przekraczało 500 ziarn $/ \mathrm{m}^{3}$. Drugi typ sezonu rozpoczynał się wcześniej (w I dekadzie kwietnia lub wcześniej), trwał ponad 20 dni i charakteryzował się większą zmiennością maksymalnego dobowego stężenia ziarn, często z występowaniem wtórnego maksimum. Stwierdzono związek pomiędzy typem sezonu pyłkowego a warunkami meteorologicznymi panującymi w okresie poprzedzającym sezon oraz wykazano wpływ typów cyrkulacji, rodzaju mas powietrza i frontów atmosferycznych przechodzących w danym dniu nad południowo-wschodnią Polską na występowanie dni z dobowym stężeniem pyłku brzozy powyżej 80 ziarn $/ \mathrm{m}^{3}$, podczas których nasilają się objawy alergiczne u osób uczulonych. 
